\title{
Terrorism in Indonesia, the Philippines and Thailand, 1970 to 2008
}

\author{
Gary LaFree, Erin Miller and Sue-Ming Yang*
}

\begin{abstract}
In this paper we use the Global Terrorism Database to examine terrorist attacks from 1970 to 2008 in Indonesia, the Philippines and Thailand. In support of a special effects model, terrorism trends and characteristics in each country are distinctive. 77 percent of all terrorism in Thailand occurred between 2004 and 2008, peaking in 2007. In contrast, since the Jemaah Islamiya suicide bombings in Kuta, Bali in 2002, the frequency of terrorist activity in Indonesia has declined dramatically. Terrorism in the Philippines has been a considerable threat continuously since the late 1970s, with an average of over 80 attacks per year since 2000. In short, in the Philippines terrorism is more dispersed and constant than in Indonesia and Thailand.
\end{abstract}

Keywords: Terrorism, Philippines, Thailand, Indonesia, ASEAN, Global Terrorism Database

Terrorismus, Philippinen, Thailand, Indonesien, ASEAN, Global Terrorism Database

$\mathrm{I}$ this article we examine terrorist attacks in Indonesia, Thailand and the Philippines: three countries of the Association of Southeast Asian Nations (ASEAN) that represent a broad cross section of experiences from this region. ${ }^{1}$ According to the Global Terrorism Database, from 1970 to 2008, 467 terrorist attacks occurred in Indonesia, 2,735 in the Philippines, and 1,150 in Thailand. The characteristics of these attacks vary considerably across the three countries. For example, Thailand differs from the other two in that it is private citizens and property that are more likely to be targeted than businesses, government or transportation. 77 percent of all terrorism in Thailand occurred between 2004 and 2008, peaking in 2007. In contrast, since the Jemaah Islamiya suicide bombings in Kuta, Bali in 2002, the frequency of terrorist activity in Indonesia has declined dramatically. In the Philippines, terrorism has been a considerable threat since the late 1970s, with an average of over 80 attacks per year since 2000. Four perpetrator organizations (MILF, NPA, ASG and $\mathrm{MNLF})^{2}$ are responsible for over three-fifths of all attacks (about 95 percent of all attacks with known perpetrators). Attacks against the military and police claimed the largest number of fatalities in the Philippines. In general, the vast majority of provinces in these three countries had very few attacks over the last four decades and just five provinces (3 percent of the total) accounted for 38 percent of all terrorist attacks: Aceh (Indonesia), Metropolitan Manila (the Philippines), and Narathiwat, Pattani, and Yala (Thailand). In short, the patterns of terrorism are very different across the

* Gary LaFree is Director of the National Consortium for the Study of Terrorism and Responses to Terrorism (START), University of Maryland., Erin Miller is Project Manager at the Global Terrorism Database, University of Maryland; and Sue-Ming Yang is Assistant Professor at National Chung Cheng University, Taiwan.

1 This material is based upon work supported by the Science and Technology Directorate of the U.S. Department of Homeland Security under Grant Award 2009-ST-108-000008, made to the National Consortium for the Study of Terrorism and Responses to Terrorism (START, www.start.umd. edu). The views and conclusions contained in this document are those of the authors and should not be interpreted as necessarily representing the official policies, either expressed or implied, of the U.S. Department of Homeland Security or START. We would like to thank our colleagues in Australia who participated fully in all aspects of this project, especially Lorraine Mazerolle, Rebecca Denning, and Gentry White. We would also like to thank Brandon Behlendorf for his work on geo-coding the data.

2 Moro Islamic Liberation Front (MILF), New People's Army (NPA), Abu Sayyaf Group (ASG), Moro National Liberation Front (MNLF). three countries: in the Philippines they are more dispersed and terrorism is more of a constant, long-term problem than in Indonesia or Thailand.

The Association of the Southeast Asian Nations (ASEAN) is a geo-political and economic organization of 12 countries situated in Southeast Asia formed in August 1967, including the founding nations of Indonesia, the Philippines, and Thailand. ASEAN seeks to foster economic growth, advance social and cultural development, and facilitate cooperative efforts to protect the peace and stability of the region. As the third largest combined economy in the world, housing nearly 10 percent of the world's population, the ASEAN group of nations is of great strategic importance. However, critics of ASEAN also identify a range of complex shortcomings of the association, principally its failure to promote human rights and democracy in Myanmar (Jones, 2008), its lack of capacity to prevent and control transnational crime problems in the region (Emmers, 2003), and its inability to lead member countries to actively embrace and enforce climate change policies (Cotton, 1999).

The rise of radical Islam (Chalk et al., 2009; Desker, 2003), coupled with separatist claims for autonomous governance (Johannen et al., 2003), further complicate the challenges associated with rising levels of political violence and crime between and within the ASEAN member countries. According to our Global Terrorism Database, since 1970 Southeast Asian countries have experienced 4,939 terrorist attacks (or 6 percent of the world's known terrorist attacks), escalating to a peak of 477 attacks throughout the region in 2008. Of the ASEAN countries, Indonesia, the Philippines and Thailand account for 87.8 percent of the region's terrorist attacks.

Counter-terrorism responses in Southeast Asia originate mostly with national governments, but also include actions taken by ASEAN and the United Nations. At the national level, the counter-terrorism response capacity of ASEAN countries has been inconsistent. Johannen et al. (2003) review national security laws in the region and find that Thailand, Indonesia and the Philippines all have terrorism laws that pre-date the attacks of September 2001 in the United States. Thailand and Indonesia acted to strengthen their laws after the 9/11 attacks. 
Indonesia also responded legislatively to the terrorist bombing in Bali in 2002, but despite this failed to ratify relevant UN resolutions (Abuza, 2003).

In an examination of government responses to terrorist financing in the region, Croissant (2007) identified two conflicting trends: a convergence on the measures needed to transform international rules into national law, but a divergence in individual states' levels of compliance and implementation. While Singapore showed strong compliance, Thailand and Indonesia trailed, and Malaysia and the Philippines were even further behind (p. 152). Deficits in legal and administrative frameworks, lack of institutional capacity, unique characteristics of financial systems and political instability all contribute to the inability of many of the ASEAN countries to comply with international laws pertaining to the control of terrorist financing.

The organization of law enforcement resources in the region also adversely affects ASEAN country responses to transnational and terrorism-related problems. Filler (2002), for example, found that the Philippines' failure to adequately respond to the rise of the Abu Sayyaf Group was likely caused by overlapping mandates of police and military agencies. Similarly, Abuza (2003) identified structural problems in the Southeast Asian response to terrorism including: the fluid nature of movements such as al Qa'ida, institutional obstacles to effectively fighting terrorism at uni-, bi- and multilateral levels, the weakened organizational structures of ASEAN, the gap between United States and regional government objectives, the need to respect human rights, and the threat stemming from human rights abuses by governments possibly serving to alienate moderates who would otherwise project a viable alternative to radicals, and whose cooperation is needed for effective counter-terrorism (p. 27).

Despite these ASEAN limitations, Chalk et al. (2009) recently reviewed government responses to terrorism in the region and found reasons for "guarded optimism." Citing a new emphasis on dialoguebased responses and other more nuanced approaches to counterterrorism, rather than relying only on repression, Chalk et al. identify Indonesia, in particular, as committed to professionalizing its police and developing frameworks and resources for more effective counter-terrorism. The way forward in Indonesia centers on addressing corruption, promoting police reform, supporting regional institutions, urging the ratification of UN conventions, enhancing local governance, harnessing soft power and developing more effective communication (pp. 189-196).

\section{Profiles of Terrorism in Indonesia, the Philippines, and Thailand}

Patterns of terrorism in Indonesia, the Philippines and Thailand vary considerably. The following profiles highlight common themes and unique qualities of terrorist activity within each of the three countries. Here we examine trends in attacks over time generally as well as describe the activity of key perpetrator organizations. This analysis provides an introduction to the basic characteristics of terrorism in Indonesia, the Philippines and Thailand and illustrates ways in which they represent unique challenges.

Data for this report are drawn from the Global Terrorism Database (GTD), maintained by the National Consortium for the Study of Terrorism and Responses to Terrorism (START) at the University of Maryland. At the time this article was prepared, the full GTD included information on over 87,700 international and domestic terrorist attacks that occurred worldwide between 1970 and 2008. The data are drawn from unclassified materials, primarily media sources, published reports and chronologies. The GTD defines terrorist attacks as acts by non-state actors involving the threatened or actual use of illegal force and violence to attain a political, economic, religious or social goal through fear, coercion, or intimidation (LaFree and Dugan, 2007). Each record in the GTD includes available information on over 120 variables pertaining to the date, location, tactics, weapons, targets, perpetrators and outcomes of the attack (see www.start.umd.edu/gtd).

Figure 1 shows terrorism trends for the three countries examined here between 1970 and 2008. The frequency of attacks differs considerably across these three countries. While the Philippines experienced the bulk of its terrorist activity from the mid-1980s to the mid-1990s, Indonesia was most active during the 1990s, and terrorist attacks in Thailand were relatively infrequent until a surge at the beginning of the 21st century. We next consider trends separately for each of the three countries.

Figure 1: Terrorist Attacks in Indonesia, the Philippines, and Thailand, 1970-2008

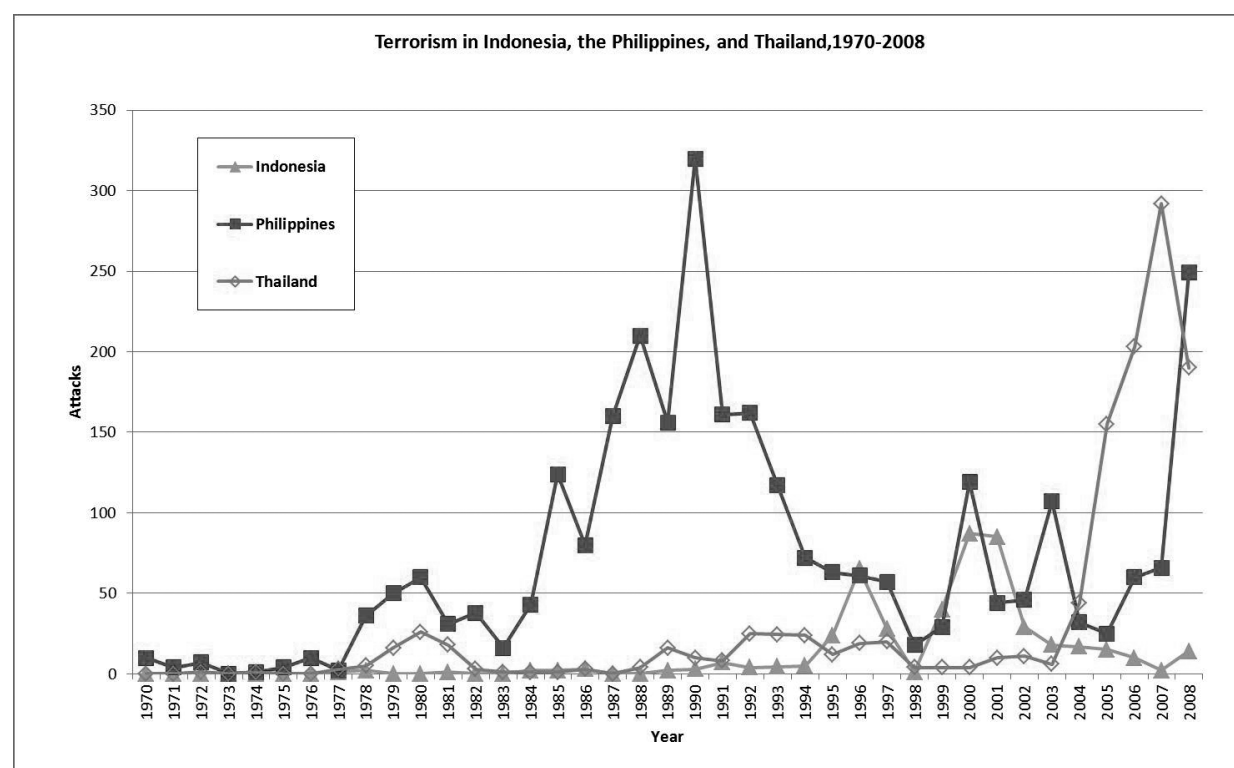

Source: Global Terrorism Database 
Figure 2: Terrorism in Indonesia, 1970-2008

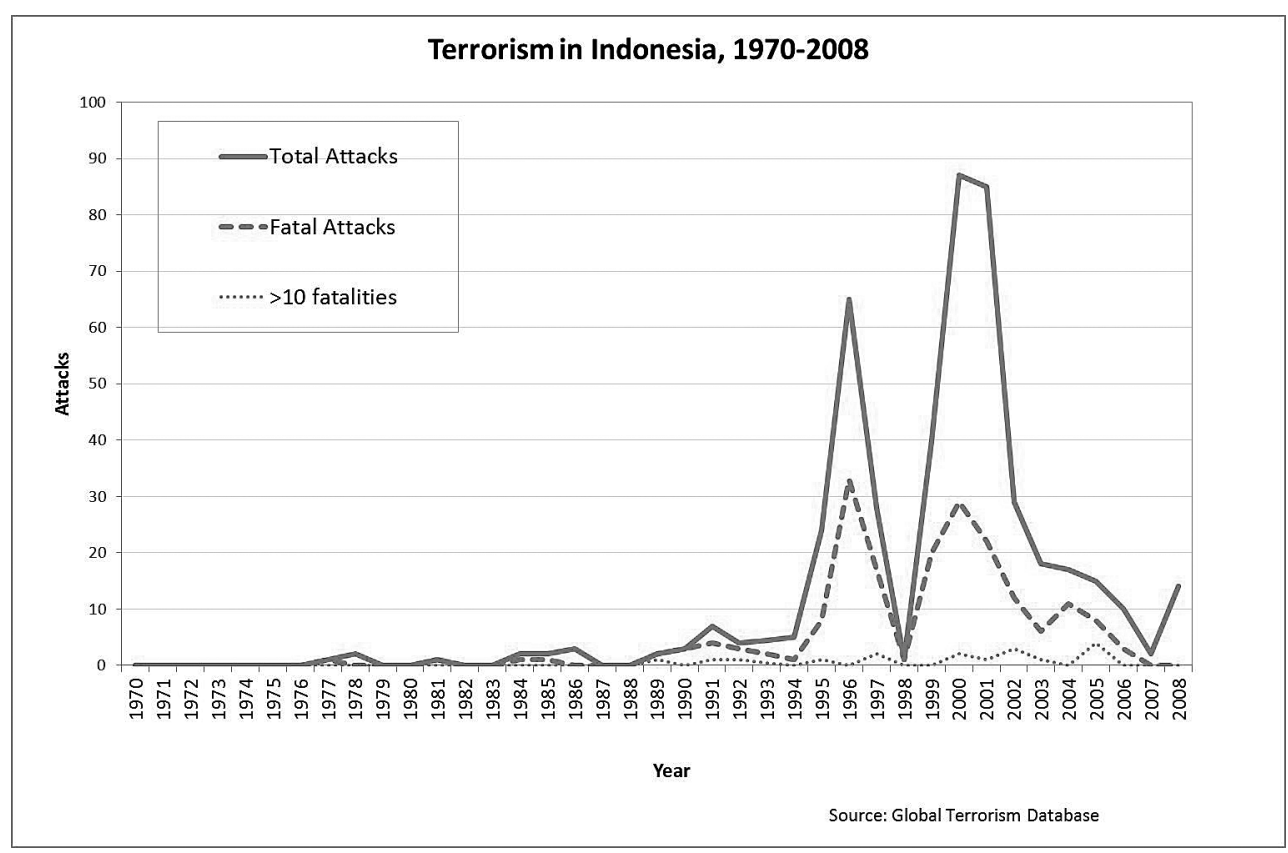

According to Figure 2, there were 467 terrorist attacks in Indonesia between 1970 and 2008, including 187 fatal attacks, and 17 attacks with over 10 people killed. A total of 928 people were killed by terrorist attacks in Indonesia during this time period. The vast majority of terrorist activity began in the early 1990 s and increased rapidly in the mid1990s, peaking in 1996 with 65 attacks that year, and again in 2000 and 2001, with over 80 attacks each year. The most lethal attacks in Indonesia were the 2002 night club suicide bombings carried out by Jemaah Islamiya in Kuta, Bali, which killed 202 people. Since then, the frequency of terrorist activity in Indonesia has declined dramatically and in the last five years of the series averaged approximately ten attacks per year.

Information on perpetrators is available for 65 percent of the attacks that took place in Indonesia. According to the GTD, the peak in terrorism in Indonesia between 1995 and 1997 is largely attributed to unknown or generically identified perpetrators such as "Muslim militants," or "East Timorese activists", which combined represent nearly 80 percent of the 112 attacks during this time period. For the entire 1970 to 2008 time span, four perpetrator organizations are attributed responsibility for over 90 percent of the incidents in which a perpetrator is identified: the Free Aceh Movement (GAM), Jemaah Islamiya (JI), the Free Papua Movement (OPM-Organisasi Papua Merdeka), and the Revolutionary Front for an Independent East
Timor (FRETILIN). The frequency of attacks attributed to these four groups are shown in Figure 3.

OPM and FRETILIN have been sporadically active since the late 1980s with at most five attacks in a given year. OPM, which was formed in the 1960s (Jenkins, 1995), has been engaged in lethal terrorist violence for at least 15 years. The GTD indicates that OPM was implicated in eight attacks since 2008, only one of which resulted in fatalities. FRETILIN was responsible for the most lethal attack in Indonesia prior to the 2002 Bali bombings, a 1989 explosion at an ammunition dump in Dili that killed 84 Indonesian soldiers and injured 27 more. FRETILIN's terrorist activity peaked and concluded in 1997 with five attacks that year, after which they became a ruling political party coinciding with the independence of East Timor.

In contrast to these other groups, the activity of JI and GAM is characterized by shorter periods and less frequent attacks, but nonetheless highly lethal activity. JI's activity in Indonesia peaked in 2000 with 40 attacks, 39 of which occurred on Christmas Eve; and GAM's attacks peaked in 2001 with 58 attacks that occurred on only 30 unique dates. JI's activity in particular is characterized by relatively few, highly lethal, coordinated attacks that involve explosives detonated in multiple locations. Following the 39 coordinated bombings on December 24, 2000, which killed 19 and injured 117, they
Figure 3: Indonesia: Major Organizations, 1989-2008

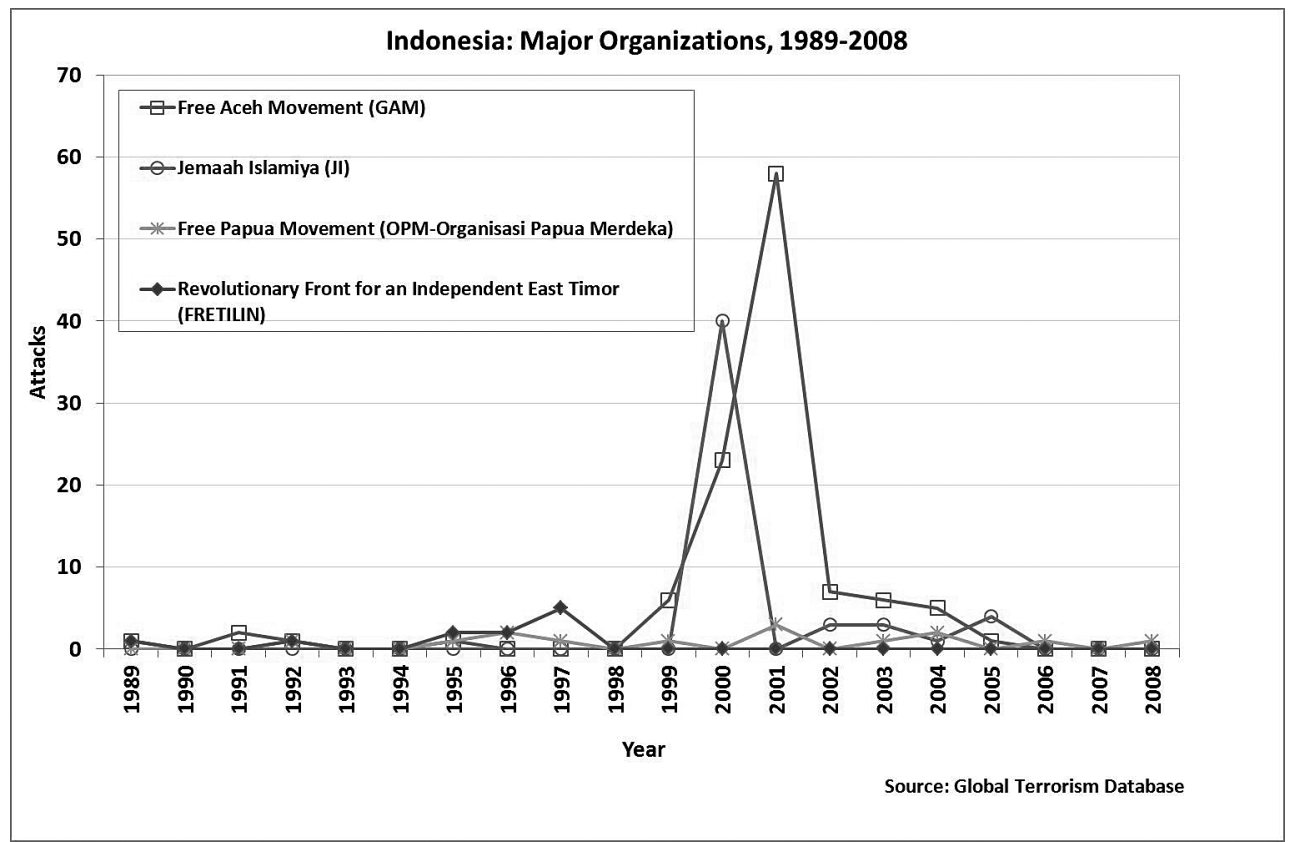


Figure 4: Indonesia: Target Type 1970-2008

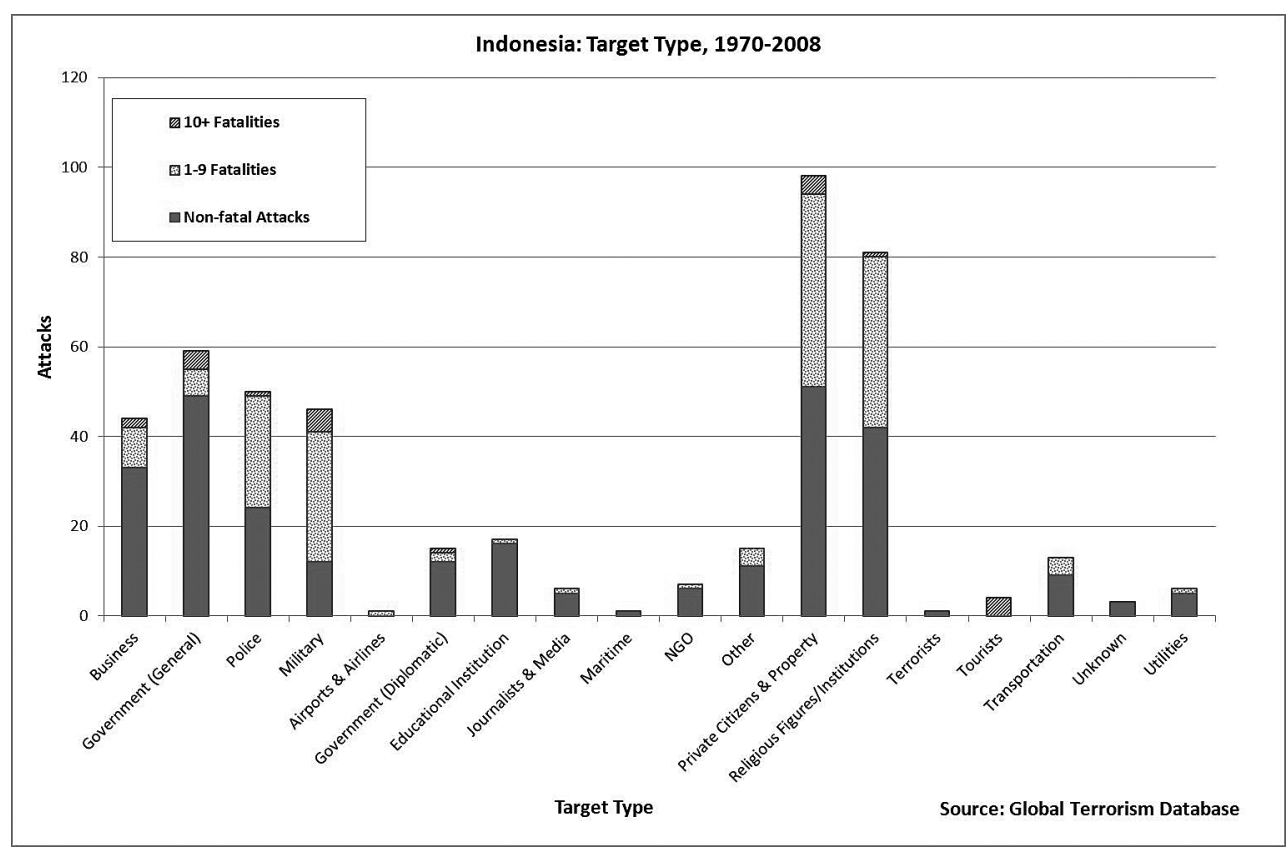

carried out no attacks in 2001. In 2002, the year of the deadly Bali night club bombings, JI carried out only three attacks, all on the same day. The third JI attack that day targeted the United States Consulate in Denpasar, Bali but caused no deaths. In their only lethal attack in 2003 JI killed 15 in a suicide attack at the JW Marriott hotel in Jakarta. Their only attack in 2004 killed ten at the Australian Embassy in Jakarta. Two coordinated attacks in May 2005 and two coordinated attacks in October 2005 killed a total of 47 persons. Following a period of inactivity during which Indonesian authorities cracked down on JI operatives ("NGO hails Indonesia," 2009), they carried out coordinated suicide attacks targeting the JW Marriott and the Ritz-Carlton hotels in Jakarta in July 2009, killing nine and wounding 50 more.

In contrast to JI, GAM killed 65 people during their peak year, 2001. Since then their activity has declined to only seven attacks in 2002, fewer attacks each subsequent year, and no attacks recorded since 2005 (when GAM signed a peace accord with the Indonesian government following talks that began after the 2004 tsunami that killed over 120,000 in Aceh province) (Brummitt, 2005; Lekic, 2005).

In Figure 4, we show the targets of terrorist attacks in Indonesia. The most common target type is private citizens and property, followed by religious figures and institutions, each representing over 80 attacks between 1970 and 2008. For both of these target types, approximately

Figure 5: Terrorism in the Philippines, 1970-2008 half of all attacks are lethal. Other common targets in Indonesia include government (general, nondiplomatic), police, military, and business which comprise nearly 200 attacks combined during this time period. While attacks against business and government targets seldom caused fatalities, attacks against military targets killed at least one person in 74 percent of all cases.

Although rare, the attacks against tourist targets in Indonesia were all highly lethal. Included in this category are the tourists killed in the 2002 night club attacks in Bali, which are the most lethal attacks against tourist targets recorded for any country in the world since 1970. The prevalence of attacks against religious figures and institutions in Indonesia is also striking. These types of targets make up only 2 percent of all terrorist attacks worldwide, but over 17 percent of attacks in Indonesia. The targets represented in this category include primarily Christian churches and individuals affiliated with them.

\section{Terrorism Trends and Characteristics in the Philippines}

According to Figure 5, a total of 2,733 terrorist attacks took place in the Philippines between 1970 and 2008. Of these, 1,449 were fatal and 143 caused more than 10 fatalities. During this time period 6,617 people were killed in terrorist

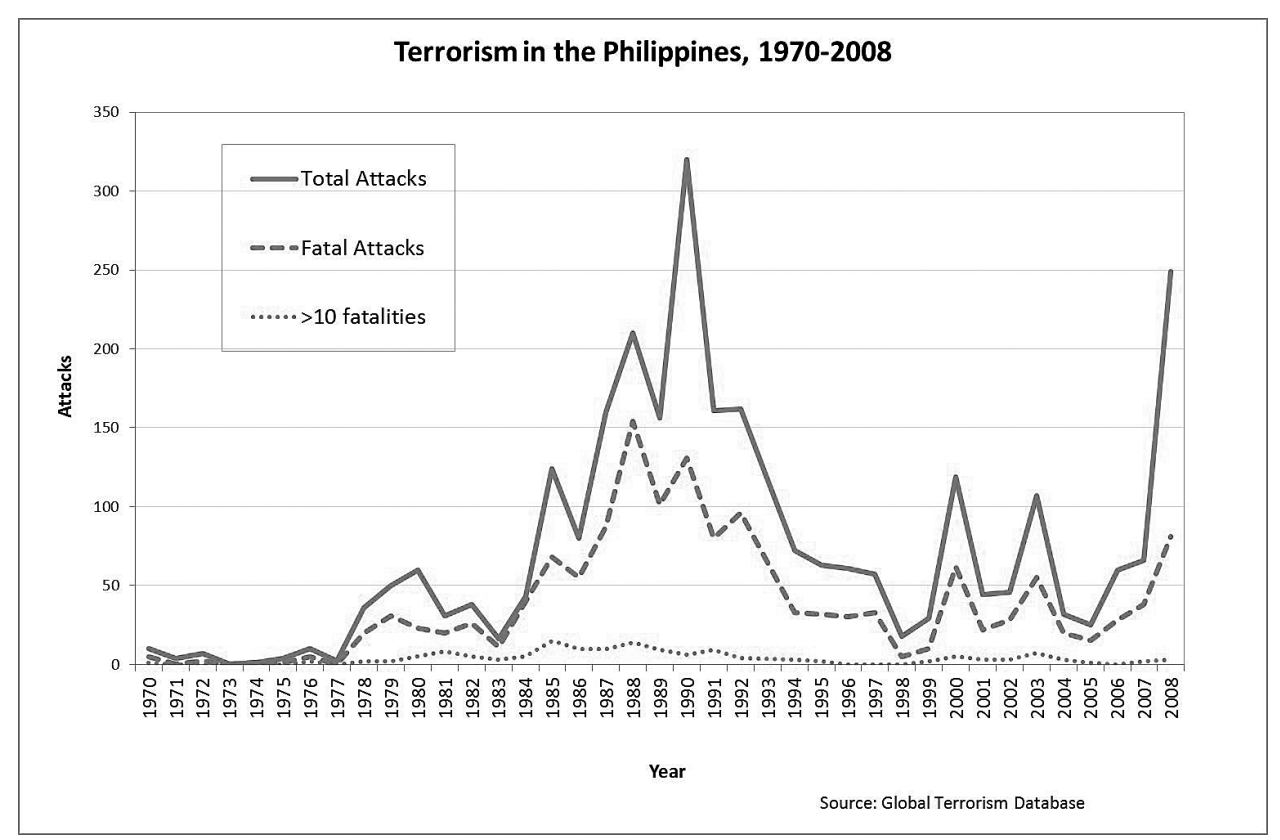


attacks in the Philippines. Unlike Indonesia, which experienced fairly low levels of terrorist activity until the mid-1990s, terrorism in the Philippines has been a considerable threat since the late 1970 s and early 1980s. Although activity peaked at over 300 incidents in 1990 and subsequently declined until 1998, the Philippines has had, on average, over 80 terrorist attacks per year since 2000. The most lethal attack in the Philippines was carried out by the Abu Sayyaf Group in February 2004 against the Superferry 14 in Manila Bay. An ASG operative placed an explosive device made of approximately eight pounds of TNT in a television set and detonated it using a watch as a timer. The explosion caused a fire that destroyed the vessel and killed 116 people.

Information about perpetrators is available for 73 percent of attacks in the Philippines. Four perpetrator organizations are responsible for over 95 percent of all attacks with known perpetrators, the New People's Army (NPA), the Moro Islamic Liberation Front (MILF), the Moro National Liberation Front (MNLF), and the Abu Sayyaf Group (ASG). Total attacks attributed to these four groups are shown in Figure 6. Of these groups, the NPA, which is the military wing of the Communist Party of the Philippines, has been the most active with over 1100 attacks dating back to the first year of GTD coverage, one year after their formation in 1969 (Chalk et al., 2009). NPA attacks are mostly against military, police, and government entities which, combined, represent 64 percent of their targets. Between 1970 and 2008 over 66 percent of NPA attacks were lethal; however, this statistic has declined considerably over time from 86 percent in the 1970s, to 73 percent in the 1980s, to 63 percent in the 1990s, and 51 percent in the 2000s. Following a period of relatively little activity from the mid-1990s through the mid-2000s, the NPA has recently been implicated in many attacks, albeit frequently against telecommunication, transportation, and utilities targets and usually with few or no casualties.

The MNLF and its successor, the MILF. have similarly been active since the 1970s. Both of these organizations often target private citizens and property as well as military targets, although the MNLF also carried out many attacks against business targets. The MILF splintered off the MNLF following conflicts within the group between 1977 and 1984 over the willingness to engage in insurgency in pursuit of a completely independent Islamic state (Chalk et al., 2009; Cragin et al., 2007). The two groups coexisted until the MNLF reached a compromise with the government in 1996 that afforded some degree of autonomy to areas of the Philippines with Muslim majorities (Chalk et al., 2009), at which time the activity of the MNLF nearly ceased, while the violence of the MILF increased dramatically.
Combined, the MNLF and MILF carried out 451 terrorist attacks between 1975 and 2008, killing over 1,300 persons.

The Abu Sayyaf Group (ASG), which also splintered from the MNLF in opposition to compromise with the government, has been operational since the early 1990s and is responsible for the two most deadly attacks in the Philippines. The first was the April 1995 raid against the town of Ipil, when 114 were brutally murdered, including 73 residents and hostages and 41 guerrillas. This attack, which occurred at lunchtime, was well orchestrated and carried out by several hundred rebels wearing military fatigues and arriving in both trucks and boats, armed with assault rifles, rocket-propelled grenade launchers and U.S.-made B-40 anti-tank weapons (Alabastro, 1995a). Note that although the Philippines government attributes responsibility for this attack to ASG, an unknown MNLF splinter calling itself the Islamic Command Council issued a letter claiming responsibility and accusing the MNLF of betraying their cause by engaging in peace talks with the government (Alabastro, 1995b). The second and most lethal attack was the Superferry bombing in February 2004 that took 116 lives. ASG carried out 141 terrorist attacks between 1994 and 2008, resulting in 450 fatalities.

In Figure 7 we show the distribution of terrorist targets for attacks taking place in the Philippines. The most common types of targets of terrorist attacks in the Philippines are military, private citizens and property, business, government (non-diplomatic), and police. Combined, these types of targets comprise over 75 percent of all terrorist attacks in the Philippines between 1970 and 2008, which is fairly typical for the distribution of terrorist targets in the GTD worldwide. Compared to attacks on other types of targets, attacks against business targets in the Philippines are disproportionately likely to involve no fatalities, while attacks against military and police targets are more likely to be fatal. Attacks on police are especially deadly with an average of more than ten deaths per attack. 


\section{Terrorism Trends and Characteristics in Thailand}

Figure 8 shows attacks, fatal attacks and mass casualty attacks in Thailand. Unlike patterns of terrorist activity in Indonesia and the Philippines, which include a great deal of activity prior to the 21st century, terrorism in Thailand is heavily concentrated after 2004, coinciding with the growth of a separatist insurgency ("Thailand's southern insurrection," 2004), particularly in the southern provinces of Pattani, Yala, and Narathiwat. Despite sporadic occurrences of up to 25 attacks per year in the 1980s and increased activity in the 1990s, over 75 percent of all terrorism in Thailand occurred between 2004 and 2008, peaking at nearly 300 attacks in 2007. A total of 1,140 terrorist attacks occurred in Thailand between 1970 and 2008, 631 of which were fatal. Attacks that killed more than ten people are rare in Thailand, occurring only eight times between 1970 and 2008. The most lethal attack in Thailand occurred in 1979 when Communist insurgents ambushed an Army patrol in the Nam Son District with explosives, firearms and rocket-propelled grenades, taking 27 lives.

In contrast to Indonesia and the Philippines, terrorism in Thailand is considerably less concentrated among a small set of clearly identified perpetrator organizations. In 74 percent of terrorist attacks in Thailand there is no information reported about the perpetrators. Furthermore, the top five organizations

Figure 8: Terrorism in Thailand, 1970-2008

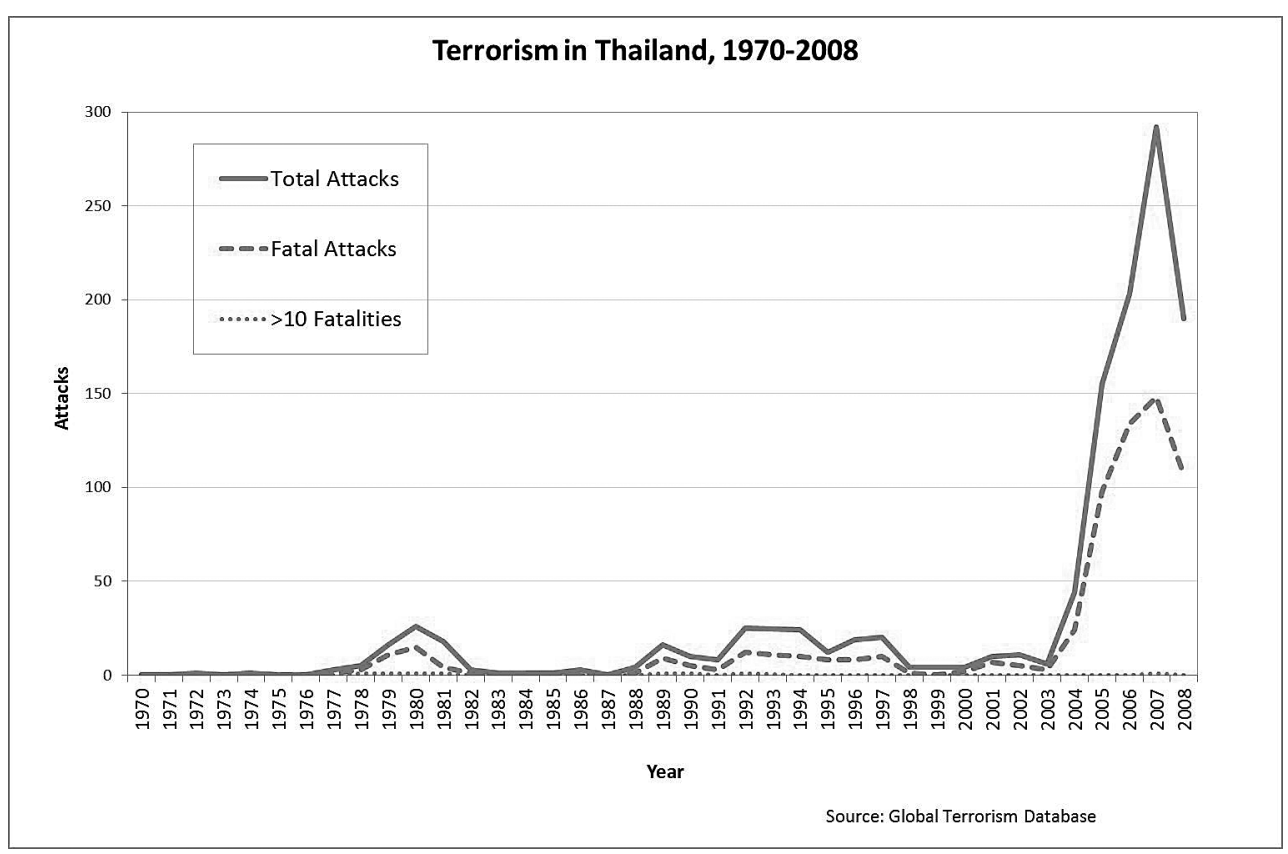

account for only 75 percent of all attacks in which some information about the perpetrators is known. These five are, in order of total attack frequency, the Pattani United Liberation Organization (PULO), the Democratic Karen Buddhist Army (DKBA), the Runda Kumpulan Kecil (RKK) group, Barisan Revolusi Nasional (BRN), and the Karen National Union (KNU). In Figure 9 we show trends for these five groups. Note that due to the small numbers of attacks attributed to these groups these trends must be interpreted with caution.

According to Figure 9, of the five major groups operating in Thailand, the separatist group PULO has been active for the longest, carrying out terrorist attacks since the 1970s. These attacks by PULO are usually not lethal and most often target business (35 percent), transportation (26 percent), and police (19 percent). Related separatist groups BRN and RKK have been active only since the insurgency that began in 2004 . The KNU and its splinter, the DKBA, are both ethnic Karen groups based in Myanmar that have attacked both Thai and Burmese targets in Thailand since the 1990s. They are active primarily in Burmese refugee camps in Mae Sot on the ThailandMyanmar border. These attacks resulted in at least one death in over 60 percent of the cases.

We show the distribution of target types for Thailand in Figure 10. The most striking pattern for Thai target types is the predominance of attacks against private citizens 
Figure 9: Thailand: Major Organizations, 1970-2008

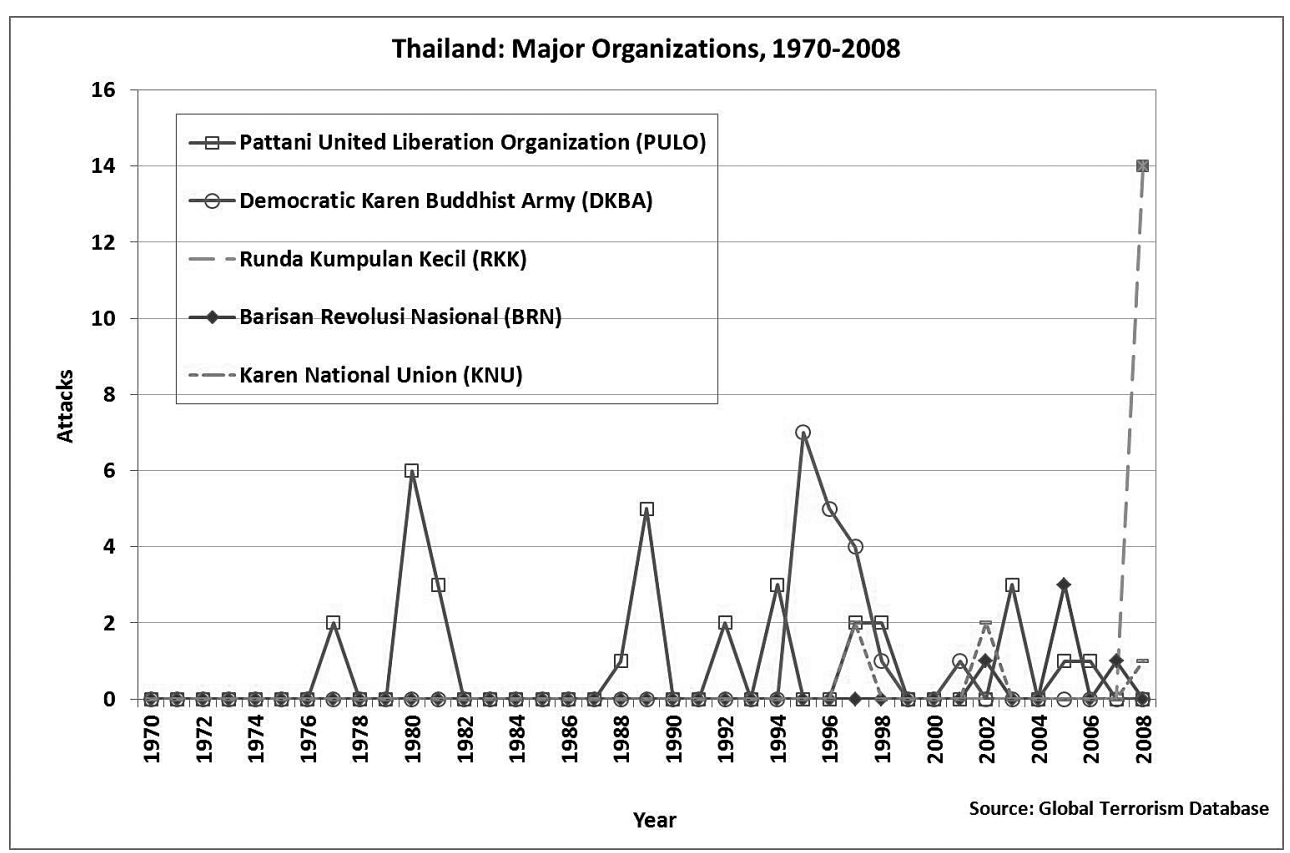

and property. Between 1970 and 2008, 38 percent of all terrorist attacks fell into this category, over three times as many as the next most common types, government (non-diplomatic) and police. Although private citizens and property is the most commonly identified type of target in the GTD worldwide (representing 20 percent of all attacks), it is nearly twice as prevalent in Thailand. This category also represents the greatest concentration of fatal terrorist attacks in Thailand. Attacks against business and transportation targets are lethal in fewer than 25 percent of cases, attacks against government, police, and military targets are lethal in roughly half of all cases, and attacks against private citizens and property are lethal in over 70 percent of attacks. or whether terrorism risk was similarly distributed everywhere (Østby et al., 2007). This type of inquiry has both theoretical and policy implications. Much work in criminology (Sherman et al., 1989) shows the disproportionate contribution of a relatively small number of crime "hot spots" to overall crime rates. That is, a small proportion of geographic units account for a large number of crimes. The classic study by Wolfgang, Figlio, and Sellin (1972) found that 8 percent of a cohort of juvenile offenders in Philadelphia were responsible for over 50 percent of reported crime. The same phenomenon is found in the study of terrorism across countries. Thus, LaFree, Morris and Dugan (2010) report that worldwide only 15 percent of countries account for 86 percent of total terrorist attacks. Similar reasoning supports the utility of determining how concentrated terrorist attacks are in the three countries being examined. If terrorist attacks are randomly distributed across locations, then efforts to understand place-related characteristics, such as demographic composition or political orientation, will not be useful for understanding or forecasting terrorist attacks. More generally, we are interested in exploring the extent to which terrorist attacks in these three countries follow either a joint effects model, where terrorism trends show substantial underlying similarities, or a special effects model, where terrorism trends in each country are distinctive and unique.
We now turn to an examination of geographic patterns of terrorist attacks at the province level. As we have seen in the previous section, all three countries included in this analysis experienced substantial increases in terrorist attacks for the last two decades-although we also observed considerable variability across the three countries.

\section{Provincial Level Trends in Terrorism}

While the country-level analysis shows different patterns of terrorist attacks for Indonesia, the Philippines and Thailand, it does not tell us whether smaller geospatial units within any country had similar risks of being attacked
Figure 10: Thailand: Target Types, 1970-2008

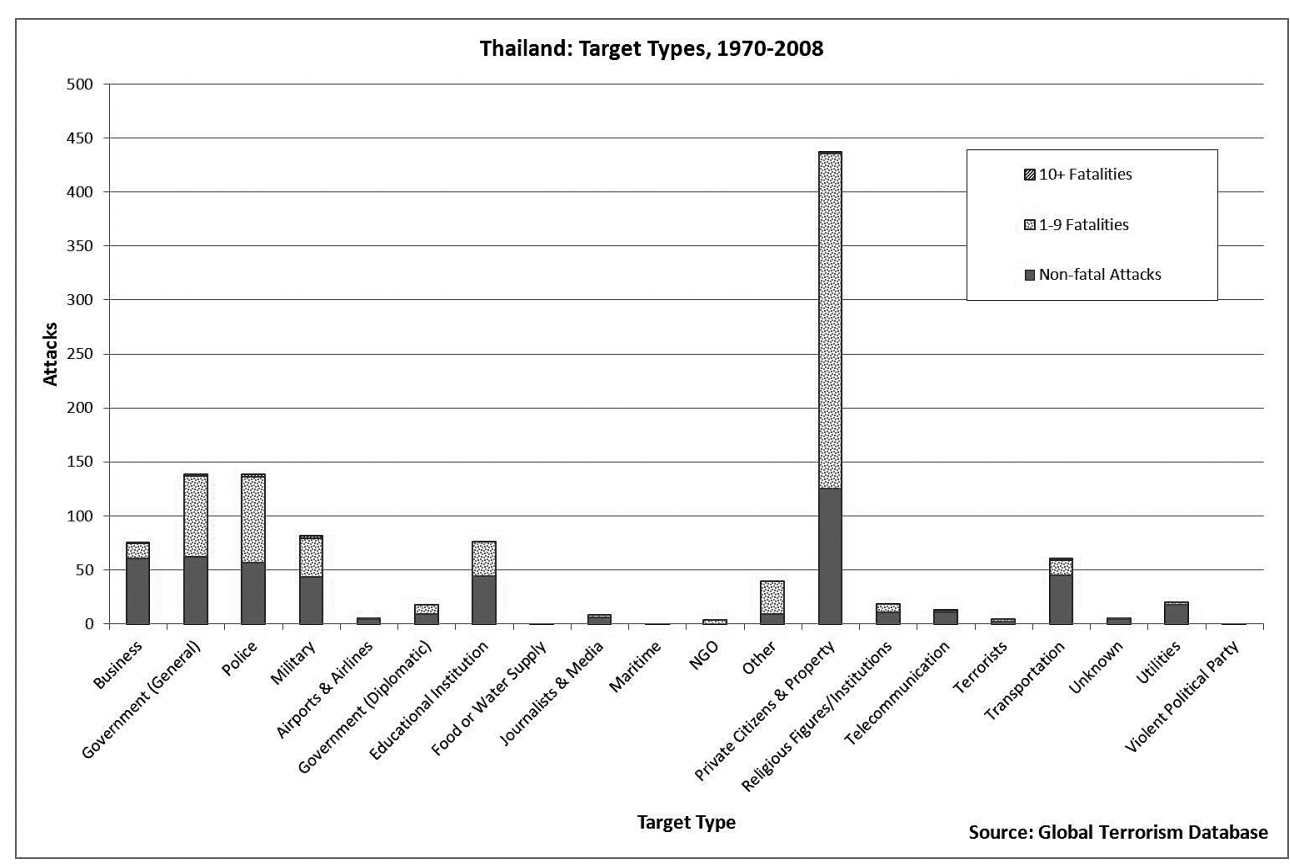


Figure 11: Density of Terrorist Attacks in Indonesia

\section{Geographic Distribution of Terrorist Attacks in Indonesia}

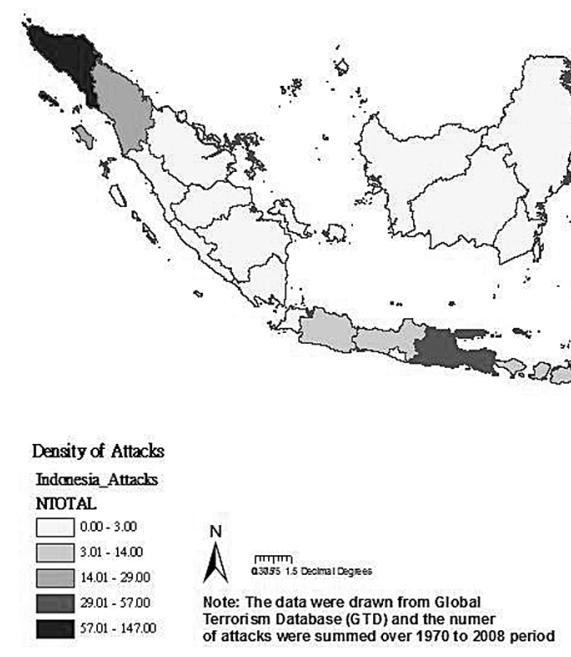

Figure 12: Density of Terrorist Attacks in the Philippines

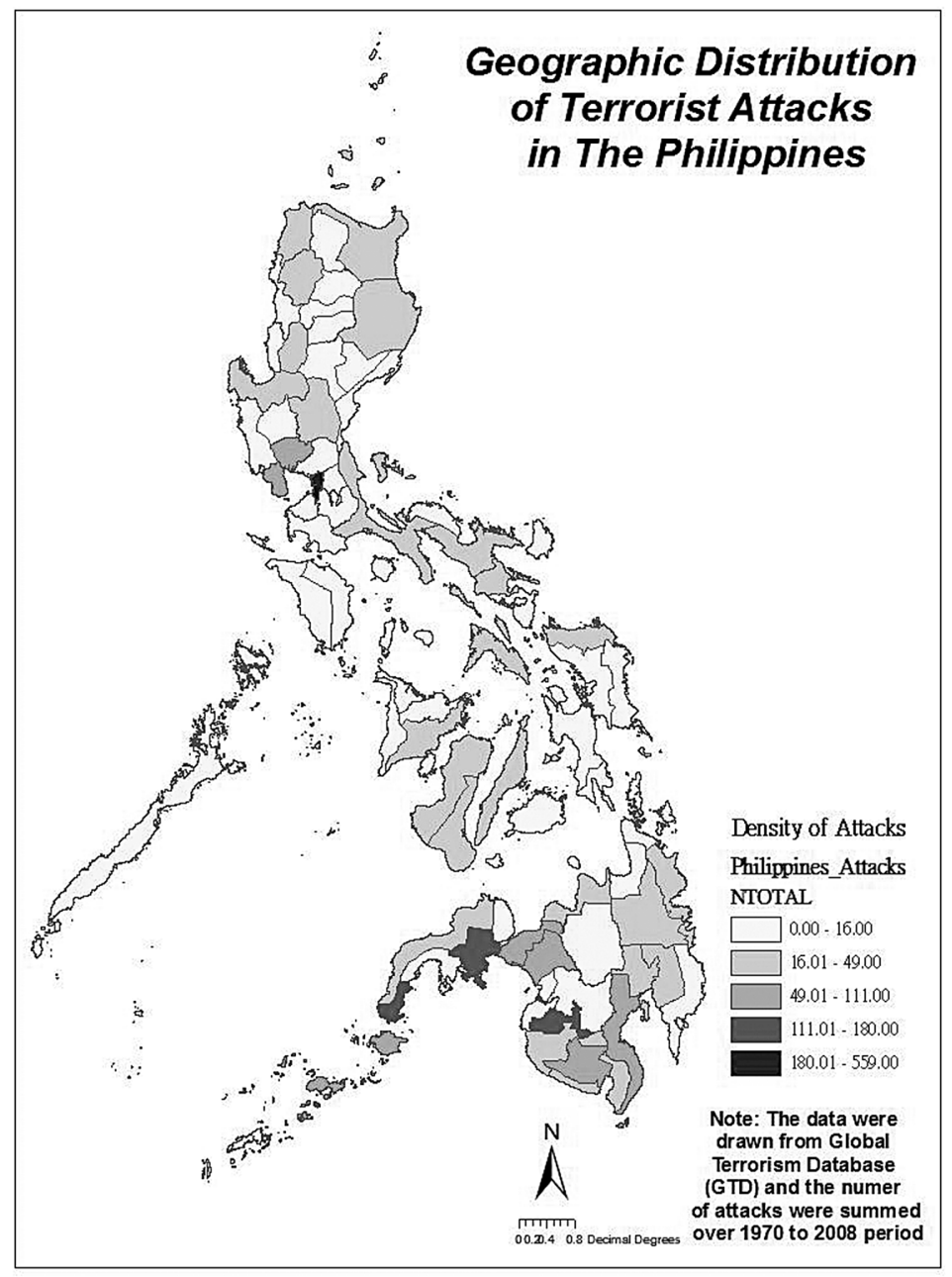

Despite the apparent utility of examining terrorism at the sub-state level, few prior studies of these three countries have done so. An exception is Østby et al. (2007), who examine province level data on terrorism for Indonesia and conclude (p. 2) that aggregate-level state characteristics cannot explain why conflicts arise in specific local areas within countries. To better understand these issues, we next examined terrorist attack patterns at the province level. From a policy standpoint, if attacks are limited mostly to specific areas, then we might allocate scarce resources especially into these areas rather than apply blanket prevention measures across an entire country. Moreover, our comparison of provincial trends across countries will give us insight into whether a regional counterterrorism policy is sufficient or whether provincial level patterns within each country reflect more idiosyncratic patterns.

Finally, it may be that the design of appropriate counterterrorism strategies depends on the unique demographic composition and the political atmosphere of local regions. This rationale justifies the analysis of both the temporal and geographic distribution of terrorist incidents at the province level.

To geo-code the GTD cases to the province level we began with automated coding to identify the latitude and longitude of the city, village, or town where the incident occurred using the National Geospatial-Intelligence Agency's (NGA) GeoNet Names Server (GNS) and then used Google Earth and open geo-intelligence sources to review the matches identified in the automated coding process. These procedures resulted in complete data for 189 provinces (98 percent of all cases) across the three countries: 34 provinces in Indonesia, 79 provinces in the Philippines, and 76 provinces in Thailand. ${ }^{3}$

\section{Geographic Distributions of Terrorism}

In Figure 11 we show the concentration of terrorist attacks in Indonesia over the 39-year study period. The density of terrorist incidents is represented by the color of the corresponding area on the map; darker color means a higher concentration of attacks in the area. According to Figure 11, the areas with the highest number of terrorist attacks are concentrated in western regions and in more localized areas in the center of the

3 In cases where provinces were subdivided we chose to keep the original boundaries. 
island chain. Specifically, in the West, Aceh had the highest number of attacks (147) over the time period while Timor-Leste, which established independence in 2002, had the second highest number of attacks (77). Other areas had much lower numbers of attacks. The majority of Indonesian provinces had fewer than two attacks, and 10 provinces in Indonesia did not have a single attack over the 39-year period.

In Figure 12, we show the distribution of terrorist attacks in the Philippines. Perhaps the most obvious visual difference between Indonesia and the Philippines is that in the latter, attacks are more widely dispersed throughout the country. Metropolitan Manila in the north, also known as the National Capital Region, has the highest number of terrorist attacks (559) in the country. Other high-frequency provinces are located in the Southwestern part of the country, with Zamboanga Del Sur (Sibugay), Maguindanao, Cotabato, and Davao Del Sur all having over 100 attacks during the period spanned by the data.

In Figure 13 we show the distribution of terrorist attacks in Thailand from 1970 to 2008. In contrast to Indonesia and even in stronger contrast to the Philippines, the distribution of terrorist attacks in Thailand is very concentrated with only a few provinces having more than one attack over the entire study period. About 79 percent of all terrorist attacks in Thailand are concentrated in just three southernmost provinces: Yala, Narathiwat and Pattani.

In general, the geographic distribution of terrorist attacks over time for these three countries provides more support for special effects than joint effects models. In all three countries, terrorism is highly concentrated at the province level, but within countries the patterns are distinctive. While terrorism in the Philippines is relatively dispersed, terrorism in Indonesia is heavily concentrated in the Capital and in the Southwest, and terrorism in Thailand is to a large extent limited to three southern provinces.

\section{Summary and Conclusions}

Our analysis of terrorism trends in Indonesia, Thailand and the Philippines shows that much of the activity in these three countries over the past four decades has been concentrated in only a few provinces. The Philippines had the most activity in the 1970s and 1980s, while terrorist attacks were relatively rare in both Indonesia and Thailand during this period. By contrast, in the 1990s, the number of attacks in Indonesia
Figure 13: Density of Terrorist Attacks in Thailand

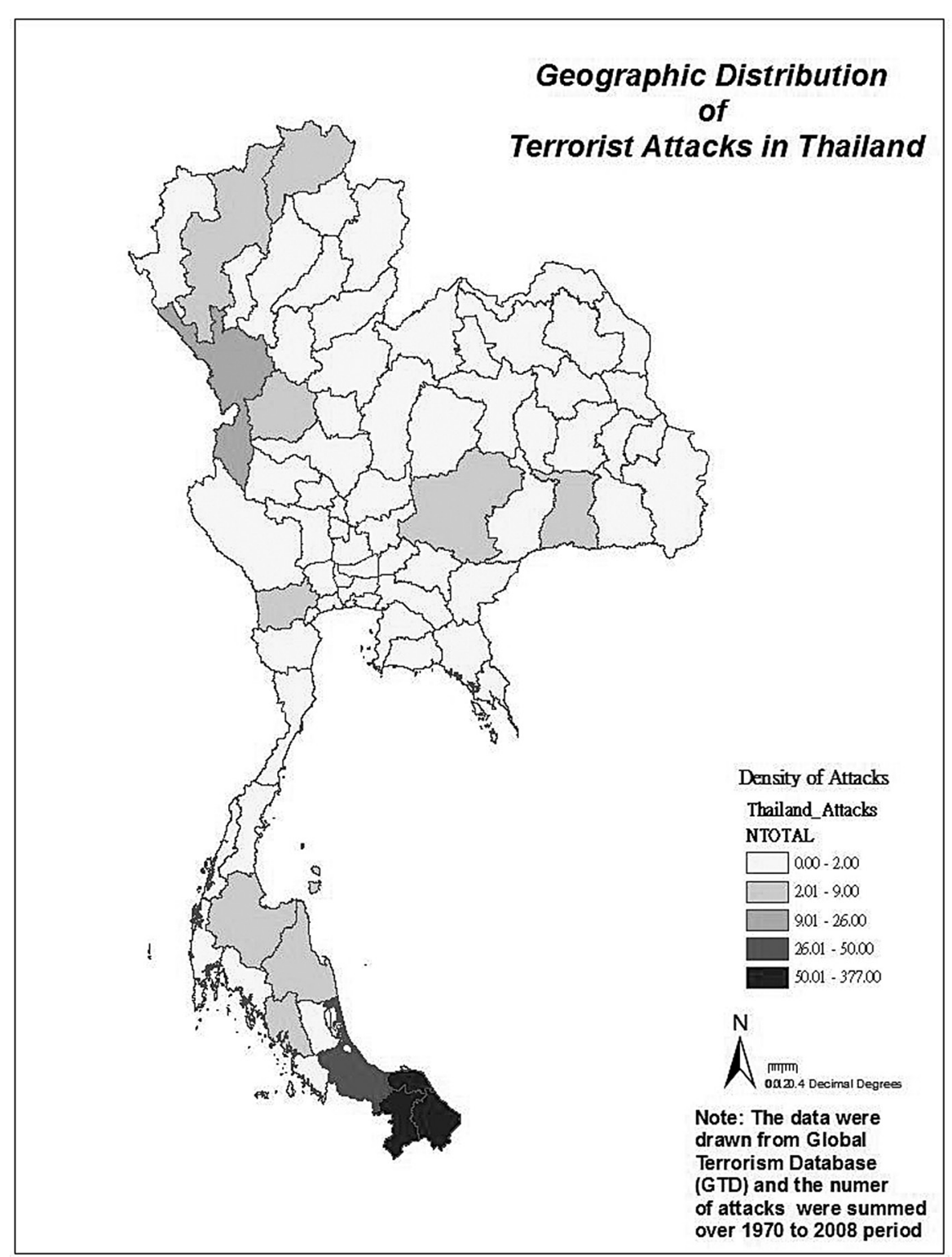

increased rapidly while declining in the Philippines. Finally, in recent years terrorist activity in Thailand began to escalate as activity in Indonesia declined.

We have seen above that these patterns are largely driven by the activity of several key groups of perpetrators in the three countries. In the Philippines, the NPA was responsible for 43 percent of all attacks between 1970 and 2008 and 75 percent of the attacks between 1985 and 1995. In Indonesia, the violence that occurred as East Timor established its independence at the turn of the twenty-first century was accompanied by the relatively infrequent but lethal attacks of JI as well as a concentrated series of attacks by GAM, before both groups' attacks declined dramatically in recent years. In the case of JI, the decline coincided with hundreds of arrests and prosecutions of its members, and for GAM with a peace agreement with the government. In Thailand the perpetrators are less clearly concentrated and organized, rather, the recent spike in violence is almost exclusively the 
work of unidentified, unaffiliated attackers associated with the separatist insurgency in the South.

Overall, we find extreme concentration of terrorist activities within the three countries. However, the results also show that terrorist activities in the three countries are very different in terms of level of concentration, prevalence, lethality, attack trends and even geographic distribution. In short, we find much more support for a special effects than a joint effects model of terrorism for these three countries over the past four decades. The terrorism trends and geospatial distributions in these countries are very distinctive, and while general trends in the region have increased during the past decade, the rate and shape of these increases varies greatly across countries and across provinces within countries.

\section{References}

Abuza, Z. (2003). Militant Islam in Southeast Asia: Crucible of Terror. Boulder, CO: Lynne Rienner Publishers.

Alabastro, R. (1995a, April 4). Philippine rebels kill 26, leave town in flames. Reuters. Retrieved from http://www.lexisnexis. com.

(1995b, April 11). Breakaway group claims Ipil raid, battle continues. Reuters. Retrieved from http://www. lexisnexis.com.

Brummitt, C. (2005, December 27). Aceh rebels disband armed wing, one year after tsunami

destroyed their battlefield. Associated Press Worldstream. Retrieved from http://www.lexisnexis.com.

Chalk, P., A. Rabasa, W. Rosenau, and L. Piggott (2009). The evolving threat to Southeast Asia: A net assessment. Santa Monica, CA: RAND Corporation.

Cotton, J. (2003). Southeast Asia after 11 September. Terrorism and Political Violence 15, 148-170.

Cragin, K., P. Chalk, S. Daly. and B. Jackson (2007). Sharing the dragon's teeth: Terrorist groups and the exchange of new technologies. Santa Monica, CA: RAND Corporation.

Croissant, A. (2007). Muslim insurgency, political violence, and democracy in Thailand. Terrorism and Political Violence, 19, 1-18.

Desker, B. (2003). The Jemaah Islamiyah (JI) Phenomena in Singapore. Contemporay Southeast Asia 25, 489-507.

Emmers, R. (2007). Comprehensive Security and Resilience in Southeast Asia: ASEAN's Approach to Terrorism and Sea Piracy. Working Paper Number 132. S. Rajaratnamn School of International Studies: Singapore.

Filler, A. L. (2002). The Abu Sayyaf Group: A Growing Menace to Civil Society. Terrorism and Political Violence 14, 131-162.

Jenkins, D. (1995, September 2). The other Timor: Smiling policy flags in =Irian Java.' Sydney Morning Herald, p.29. Retrieved from http://www.lexisnexis.com.
Johannen, U., A. Smith, J. Gomez and Friedrich Naumann Stiftung. (2003) September 11 and Political Freedom: Asian Perspectives. Singapore: Select Publications.

Jones, S. (2008). Briefing for the new president: The terrorist threat in Indonesia and South-east Asia. The Annals of the American Academy of Political and Social Science, 618, 69-78.

LaFree, G. and L. Dugan. (2007). Introducing the Global Terrorism Database. Terrorism and Political Violence, 19, 181-204.

LaFree, G., N. Morris A. Morris, and L. Dugan. (2010). Crossnational patterns of terrorism: Comparing trajectories for total, attributed, and fatal attacks, 1970-2006. British Journal of Criminology, 50, 622-649.

Lekic, S. (2005, July 17). Indonesian government and Aceh rebels agree on draft peace deal. The Associated Press. Retrieved from http://www.lexisnexis.com

NGO hails Indonesia's legal, humanitarian approach to extremists. (2009, May 26). Republika.

Retrieved from http://www.lexisnexis.com.

Østby, G., H. Urdal, M. Murshed, and Z. Tadjoeddin (2007). Conference Papers -- International Studies Association, 2007 Annual Meeting, 1-29.

Sherman, L. W., P. Gartin, and M. E. Buerger (1989). Hot spots of predatory crime: Routine activities and the criminology of place. Criminology, 27, 27-55.

Thailand's southern insurrection is worst in half century: Deputy PM. (2004, August 24). Agence France Presse. Retrieved from http://www.lexisnexis.com.

Wolfgang, M. E., R.M. Figlio, and T. Sellin (1972). Delinquency in a birth cohort. Chicago: University of Chicago Press. 